\title{
Estrogen Promotes Pro-resolving Microglial Behavior and Phagocytic Cell Clearance Through the Actions of Annexin A1
}

\author{
Rodrigo Azevedo Loiola ${ }^{1,2}$, Edward S. Wickstead ${ }^{3,4}$, Egle Solito ${ }^{1,5}$ and Simon McArthur ${ }^{4 *}$ \\ 1 John Vane Science Centre, Barts and The London School of Medicine and Dentistry, William Harvey Research Institute, \\ Queen Mary University of London, London, United Kingdom, ${ }^{2}$ Laboratoire de la Barrière Hémato-Encéphalique, Faculty Jean \\ Perrin, EA 2465, Université d'Artois, Arras, France, ${ }^{3}$ School of Life Sciences, College of Liberal Arts \& Sciences, University of \\ Westminster, London, United Kingdom, ${ }^{4}$ Barts and The London School of Medicine and Dentistry, Institute of Dentistry, \\ Blizard Institute, Queen Mary University of London, London, United Kingdom, ${ }^{5}$ Dipartimento di Medicina Molecolare e \\ Biotecnologie Mediche, Universitá degli Studi di Napoli Federico II, Naples, Italy
}

OPEN ACCESS

Edited by:

Vance L. Trudeau,

University of Ottawa, Canada

Reviewed by:

Hirokazu Ohtaki,

Showa University, Japan

Maricedes Acosta-Martinez, Stony Brook University, United States

${ }^{*}$ Correspondence: Simon McArthu s.mcarthur@qmul.ac.uk

Specialty section

This article was submitted to Neuroendocrine Science, a section of the journal Frontiers in Endocrinology

Received: 18 March 2019 Accepted: 12 June 2019

Published: 26 June 2019

Citation:

Loiola RA, Wickstead ES, Solito E and McArthur S (2019) Estrogen Promotes Pro-resolving Microglial Behavior and Phagocytic Cell Clearance Through the Actions of Annexin A1.

Front. Endocrinol. 10:420. doi: 10.3389/fendo.2019.00420
Local production of estrogen rapidly follows brain tissue injury, but the role this hormone plays in regulating the response to neural damage or in the modulation of mediators regulating inflammation is in many ways unclear. Using the murine BV2 microglia model as well as primary microglia from wild-type and annexin $A 1$ (AnXA1) null mice, we have identified two related mechanisms whereby estradiol can modulate microglial behavior in a receptor specific fashion. Firstly, estradiol, via estrogen receptor $\beta$ (ER $\beta)$, enhanced the phagocytic clearance of apoptotic cells, acting through increased production and release of the protein AnxA1. Secondly, stimulation of either ER $\beta$ or the $G$ protein coupled estrogen receptor GPER promoted the adoption of an anti-inflammatory/pro-resolving phenotype, an action similarly mediated through AnxA1. Together, these data suggest the hypothesis that locally produced estrogen acts through AnxA1 to exert powerful pro-resolving actions, controlling and limiting brain inflammation and ultimately protecting this highly vulnerable organ. Given the high degree of receptor selectivity in evoking these responses, we suggest that the use of selective estrogen receptor ligands may hold therapeutic promise in the treatment of neuroinflammation, avoiding unwanted generalized effects.

Keywords: microglia, estrogen, phagocytosis, resolution, annexin A1

\section{INTRODUCTION}

The neuroprotective potential of the steroid hormone estrogen has been the focus of numerous investigations, with epidemiological and animal model studies suggesting it may protect in conditions as diverse as stroke, Alzheimer's disease, Parkinson's disease, and traumatic brain injury (1). Despite this, detailed understanding of the mechanisms underlying its actions in the brain remains elusive. Many studies have focused upon the direct effects of estrogen upon damaged/dying neurones, but it is only relatively recently that the relationship between estrogen and the innate defense mechanisms of the brain, principally astrocytes and microglia, has begun to be addressed $(2,3)$.

Local production of estrogen by astrocytes is one of the first responses of both male and female brain tissue to injury (4), with this production affording significant protection in vivo 
(5). Dysregulated inflammation can be extremely deleterious for the brain (6), hence studies have focused on suppressive actions of estradiol, revealing its ability to limit microglial iNOS activity (7), and production of reactive oxygen species (8), prostaglandins (9), and inflammatory cytokines (10).

However, it is becoming increasingly clear that in the absence of aggravating factors inflammation is naturally selflimiting, with many classical mediators activating resolving pathways (11). This may have significant consequences for future therapeutic development, as generalized suppression of microglial activity significantly worsens neuronal loss in several animal models $(12,13)$, indicating the complexity of the neuroinflammatory response. We hypothesized that the actions of estrogen upon microglia are more complex than simply reducing pro-inflammatory mediator production, and that it may actively promote pro-resolving/anti-inflammatory microglial behavior.

Whilst the mechanisms of neuroinflammatory resolution are relatively underexplored, significant efforts have been made to understand the drivers of this process in peripheral inflammation (14). Many mediators have been shown to aid in inflammatory resolution and repair, but a key driver of this process is the glucocorticoid-inducible protein annexin A1 (ANXA1), which we and others have shown to exert numerous pro-resolving/anti-inflammatory effects including promotion of neutrophil endothelial detachment (15) and apoptosis (16), monocyte recruitment $(17,18)$ and macrophage phagocytosis (19). CNS expression of ANXA1 is primarily localized to endothelial cells (20) and the microglia, where we have previously shown it to be a critical player in microglial efferocytosis (21). Moreover, several studies have shown that ANXA1 expression in immune and other cells can be enhanced by estradiol (22-24), suggesting that the role of this protein in anti-inflammatory/proresolving actions of estradiol merits investigation.

Microglial phagocytosis, the removal of potentially damaging threats such as invading pathogens or apoptotic cells, is central to their ability to respond to neuroinflammatory challenge. We therefore investigated the ability of estrogen to regulate microglial phagocytic clearance of apoptotic cells in unstimulated and pro-inflammatory conditions, and the consequences of estrogen treatment upon microglial phenotype, focussing on the central pro-resolving actor annexin A1.

\section{MATERIALS AND METHODS}

\section{Drugs}

Laboratory reagents and culture media were purchased from Sigma-Aldrich (Poole, UK) unless otherwise stated. The selective estrogen receptor alpha (ER $\alpha)$ agonist $4,4^{\prime}, 4^{\prime \prime}-(4-$ propyl-[1H]-pyrazole-1,3,5-triyl)trisphenol (PPT), the selective estrogen receptor beta (ER $\beta$ ) agonist diarylpropionitrile (DPN), the selective G-protein coupled estrogen receptor (GPER) agonist $( \pm)-1-\left[\left(3 \mathrm{aR}^{*}, 4 \mathrm{~S}^{*}, 9 \mathrm{bS} \mathrm{S}^{*}\right)-4\right.$-(6-Bromo-1,-3-benzodioxol5-yl)-3a,4,5,9b-tetrahydro-3H-cyclop-enta[c] quinolin-8-yl]ethanone (G1), the selective ER $\beta$ antagonist 4-[2-phenyl-5,7-bis (trifluoromethyl-)pyrazolo[1,5-a]pyrimidin-3-yl] phenol (PHTPP) and the selective GPER antagonist $\left(3 \mathrm{aS}^{*}, 4 \mathrm{R}^{*}, 9 \mathrm{bR}^{*}\right)-4$ -
(6-Bromo-1,3-benz-odioxol-5-yl)-3a,4,5,9b-3H-cyclopenta[c] quinolone (G15) were all purchased from Tocris Bioscience, UK.

\section{Cell Culture}

Murine microglial BV2 cells (25) were cultured in RPMI medium supplemented with $5 \%$ fetal calf serum, $100 \mu \mathrm{M}$ nonessential amino acids, $2 \mathrm{mM}$ l-alanyl-glutamine, and $50 \mu \mathrm{g} / \mathrm{ml}$ gentamycin (all ThermoFisher Scientific, Poole, UK) at $37^{\circ} \mathrm{C}$ in $5 \% \mathrm{CO}_{2}$. PC12 cells (ATCC) were cultured in RPMI medium supplemented with $10 \%$ normal horse serum, $5 \%$ fetal calf serum, $100 \mu \mathrm{M}$ non-essential amino acids, $2 \mathrm{mMl}$-alanyl-glutamine, and $50 \mu \mathrm{g} / \mathrm{ml}$ gentamycin (all ThermoFisher Scientific, UK) at $37^{\circ} \mathrm{C}$ in $5 \% \mathrm{CO}_{2}$.

\section{Knockdown of AnxA1 Expression}

BV2 cells $\left(1 \times 10^{5}\right.$ cells per well $)$ were transfected with shRNA plasmids targeting murine AnxA1 from the MISSION TRC shRNA collection (Sigma-Aldrich, St. Louis, MO, USA), or with an empty plasmid control (termed pKCON). Cells were transfected for $48 \mathrm{~h}$ using FuGENE HD (Promega, Madison, Wisconsin, USA) according to the manufacturer's instructions, followed by selection for stable clones using puromycin (Promega, Madison, Wisconsin, USA). Transfection was confirmed by western blot analysis.

\section{Phagocytosis Assay}

Phagocytosis was assessed as detailed previously (21). Briefly, PC12 cells were fluorescently labeled with 5chloromethylfluorescein diacetate (CMFDA; Thermofisher Scientific, UK) according to the manufacturer's instructions, and were treated overnight with $80 \mu \mathrm{M}$ 6-hydroxydopamine hydrobromide or $40 \mu \mathrm{M} \mathrm{Na} \mathrm{S}_{2} \mathrm{O}_{5}$ vehicle to induce apoptosis. Labeled apoptotic/non-apoptotic PC12 cells were then cocultured with previously plated BV2 cells at a ratio of $1: 3$ $\mathrm{BV} 2: \mathrm{PC} 12$ for $2 \mathrm{~h}$ at $37^{\circ} \mathrm{C}$ under $5 \% \mathrm{CO}_{2}$. Co-cultures were rapidly washed three times with ice-cold PBS to remove nonphagocytic cells, and cells were either detached by gentle scraping using a rubber policeman for analysis by imaging cytometer, or mounted under Mowiol mounting agent for analysis by immunofluorescence microscopy as described previously (21). Cells were examined using an ImageStream $^{\mathrm{x}}$ MKII imaging cytometer and INSPIRE software (Amnis Corporation, Seattle, WA, USA), collecting a total of 10,000 events per treatment. Typical examples of phagocytic and non-phagocytic BV2 cells are presented in Supplementary Figure 1. Imaging cytometer analysis was confirmed by parallel analysis using microscopy. All experiments were performed in triplicate.

\section{Primary Microglial Cultures}

All animal work was performed under the UK Animals (Scientific Procedures) Act, 1986. Primary murine microglial cultures were prepared from 12-week-old female AnxA1 null (26) and C57BL/6 wild-type mice $(n=6)$, according to published protocols (27). Briefly, animals were transcardially perfused with ice-cold heparinised saline under pentobarbital anesthesia and brains were removed. Tissue was cut into $\sim 1 \mathrm{~mm}^{3}$ pieces and digested by incubation with papain for $30 \mathrm{~min}$ at $37^{\circ} \mathrm{C}(1.5 \mathrm{U} / \mathrm{ml}$, 
Sigma, UK). Resulting cell suspensions were purified by filtration through $0.45 \mu \mathrm{m}$ cell strainers and by density gradient separation on a 75\%:25\%:0\% Percoll-PBS gradient (GE Johnson, UK). Following washing in PBS, cells were plated at $1.5 \times 10^{5}$ cells/well in 12-well plates and cultured in DMEM supplemented with $10 \%$ FCS, $100 \mathrm{mM}$ non-essential amino acids, $2 \mathrm{mM}$ L-alanylglutamine, $50 \mathrm{mg} / \mathrm{ml}$ gentamycin (all Life Technologies, UK), and $10 \mathrm{ng} / \mathrm{ml} \mathrm{M-CSF}$ (ThermoFisher Scientific, UK) at $37^{\circ} \mathrm{C}$ in $5 \% \mathrm{CO}_{2}$ for 10 days prior to experimentation. Phagocytosis assays were performed by microscopy as described above, with the additional step that cultures were immunostained for Ibal to identify microglia as described previously (21).

\section{Flow Cytometry Analysis}

BV2 cells were fixed by incubation in $2 \%$ formaldehyde for $10 \mathrm{~min}$ prior to labeling for $45 \mathrm{~min}$ at $4{ }^{\circ} \mathrm{C}$ with anti-AnxA1 $50 \mathrm{ng} / \mathrm{ml}$ (21), mouse anti-human ER $\alpha 4 \mu \mathrm{g} / \mathrm{ml}$ (sc-71064, Santa Cruz Biotechnology Inc., Santa Cruz, USA); mouse anti-human ER $\beta 4 \mu \mathrm{g} / \mathrm{ml}$ (sc-53494, Santa Cruz Biotechnology Inc.); goat anti-mouse GPER $5 \mu \mathrm{g} / \mathrm{ml}$ (AF5534, R\&D Systems Inc., Minneapolis, USA), APC-conjugated rat anti-mouse CD40 $2.5 \mu \mathrm{g} / \mathrm{ml}$, PE-conjugated rat anti-mouse CD206 $5 \mu \mathrm{g} / \mathrm{ml}$, or appropriate isotype controls (Catalog Nos. 17-0401-82 and 122061-82, respectively, both ThermoFisher Scientific, UK). Cells were then washed in PBS and, where appropriate, incubated at $4^{\circ} \mathrm{C}$ for $30 \mathrm{~min}$ with an AF488-conjugated secondary antibody (AnxA1, ER $\alpha, E R \beta$ : goat anti-mouse IgG, GPER chicken antigoat IgG, both diluted 1:300). Inclusion of $0.025 \%$ saponin at all stages of the immunostaining process was used to define total vs. surface AnxA1 expression. In all cases, 20,000 events were acquired using a FACSCalibur flow cytometer (BD Biosciences, Cowley, UK) equipped with a $488 \mathrm{~nm}$ argon laser; data was analyzed using FlowJo 8.8.2 software (Treestar Inc., Stanford, CA, USA) with positive events being compared to appropriate secondary antibody or isotype controls.

\section{Quantitative RT-PCR}

Total RNA was extracted using the RNeasy mini kit and genomic DNA was removed by on-column digestion using the RNase-Free DNase set, following the manufacturer's instructions (Qiagen, Crawley, UK). cDNA was synthesized using $1 \mu \mathrm{g}$ of pooled RNA from at least three replicates using SuperScript III Reverse Transcriptase (ThermoFisher Scientific, UK). Realtime PCR was performed in triplicate, with $200 \mathrm{ng}$ of cDNA per well, $1 \mu$ l of primers, and Power SYBR Green PCR master mix (Applied Biosystems, Warrington, UK), using the ABI Prism 7900HT sequence detection system (Applied Biosystems, UK). The following QuantiTect primers (Qiagen, UK) were used: ribosomal protein L32 (Rpl32; QT00131992), AnxA1 (QT00145915). A dissociation step was always included to confirm the absence of unspecific products. Relative expression was calculated as $2^{-\Delta \Delta C T}$ using Rpl32 as an endogenous control.

\section{ELISA}

$\mathrm{TNF} \alpha$, was assayed by murine-specific sandwich ELISA using commercially available kits, according to the manufacturer's protocols (ThermoFisher Scientific, UK). AnxA1 was assayed using an in-house ELISA. Briefly, a 96-well plate coated with $10 \mu \mathrm{g} /$ well of a murine monoclonal anti-ANXA1 Ab was blocked with $1 \%$ FCS in $50 \mathrm{mM} \mathrm{Na}_{2} \mathrm{CO}_{3}$ and $50 \mathrm{mM}$ $\mathrm{NaHCO}_{3}$ (pH 9.6) for $1 \mathrm{~h}$ at $37^{\circ} \mathrm{C}$, washed, and samples and a standard series of hrANXAl were then added to the plate in triplicate and incubated for $1 \mathrm{~h}$ at $37^{\circ} \mathrm{C}$. Wells were washed, and incubated with a rabbit anti-ANXA1 polyclonal $\mathrm{Ab}$, diluted 1:1,000 (Thermofisher Scientific, UK) for $1 \mathrm{~h}$ at $37^{\circ} \mathrm{C}$. Wells were washed and incubated with HRP-conjugated sheep anti-rabbit polyclonal antiserum (1:500, Bio-Rad Antibodies, $\mathrm{UK})$ for $1 \mathrm{~h}$ at $37^{\circ} \mathrm{C}$. Plates were washed and incubated with 3,3',5,5' -tetramethylbenzidine (Sigma-Aldrich, UK) for $10 \mathrm{~min}$ at room temperature; reactions were stopped by addition of $0.5 \mathrm{M} \mathrm{H}_{2} \mathrm{SO}_{4}$. A CLARIOstar spectrophotometer (BMG Labtech, Germany) was used to measure absorbance at $450 \mathrm{~nm}$; minimum sensitivity was $1.4 \mathrm{ng} / \mathrm{ml}$. Nitric oxide production was assessed using the Griess reaction for its stable proxy nitrite (28). Briefly, $100 \mu \mathrm{l} /$ well culture medium was incubated with an equal volume of Griess reagent $(1 \%$ sulfanilamide, $0.1 \%$ naphthylethylenediamine dihydrochloride, $5 \%$ phosphoric acid) for $15 \mathrm{~min}$, prior to measurement of absorbance at $540 \mathrm{~nm}$ using a CLARIOstar spectrophotometer (BMG Labtech, Germany). Nitrite production was determined by comparison with a $\mathrm{NaNO}_{2}$ standard curve; minimum sensitivity was $3 \mu \mathrm{M}$.

\section{Western Blot Analysis}

Samples boiled in $6 \times$ Laemmli buffer were subjected to standard SDS-PAGE (10\%) and electrophoretically blotted onto Immobilon-P polyvinylidene difluoride membranes (Merck, UK). Total protein was quantified using Ponceau S staining (Merck, UK) and membranes were blotted for AnxA1 using an antibody raised against murine AnxA1 (1:1,000; ThermoFisher Scientific, UK) in Tris-buffer saline solution containing $0.1 \%$ Tween-20 and $5 \%(\mathrm{w} / \mathrm{v})$ nonfat dry milk overnight at $4^{\circ} \mathrm{C}$. Membranes were washed with Tris-buffer saline solution containing $0.1 \%$ Tween20, and incubated with secondary antibody (horseradish peroxidase-conjugated goat anti-rabbit 1:5,000; ThermoFisher Scientific, UK), for $2 \mathrm{~h}$ at room temperature. Proteins were then detected using the enhanced chemiluminescence detection kit and visualized on Hyperfilm (Amersham Biosciences, Amersham, UK). Films were digitized and analyzed using ImageJ $1.51 \mathrm{w}$ software (National Institutes of Health).

\section{Statistical Analysis}

All quantified data are derived from at least three independent experiments, performed in triplicate, and are expressed as the mean \pm standard error of the mean. Data were analyzed by one- or two-way ANOVA as appropriate, with post hoc comparison using Tukey's HSD $t$-test. In all cases, $p \leq 0.05$ was taken as indicating statistical significance. 


\section{RESULTS}

\section{Estradiol Modulates Microglial Phagocytosis in a Receptor-Specific Manner}

Initial analysis by flow cytometry confirmed the expression of all three principal estrogen receptors (ER $\alpha, \mathrm{ER} \beta$, and GPER) are expressed by BV2 microglia (Figure 1A). We then investigated the ability of estrogen to modulate the phagocytosis of apoptotic PC12 cells by BV2 cells. Exposure of BV2 microglia to $17 \beta$ estradiol dose- and time-dependently enhanced the phagocytic uptake of apoptotic cells, with greatest impact after $16 \mathrm{~h}$ treatment and at $100 \mathrm{nM}$ (Figures 1B,C).

To determine which of the three estrogen receptors were responsible for the pro-phagocytic effects of estradiol, we examined the effect of treatment with specific pharmacological agonists. Treatment of BV2 cells for $16 \mathrm{~h}$ with the ER $\alpha$ selective agonist PPT was without effect (Figure 2A) but treatment with the ER $\beta$ agonist DPN significantly and dose-dependently enhanced phagocytosis (Figure 2B). In contrast, 16 h exposure to the GPER agonist G1 dose-dependently attenuated the ability of microglia to phagocytose apoptotic cells (Figure 2C). Furthering this analysis, we studied the effects of the ER $\beta$ antagonist PHTPP or the GPER antagonist G15 (each administered at their respective $\mathrm{IC}_{50}$ values) upon the response of BV2 cells to estradiol. Pre-treatment with either antagonist alone had no effect on phagocytosis of apoptotic cells, but administration of PHTPP almost completely inhibited the pro-phagocytic effect of estradiol (Figure 2D). In contrast, pre-treatment with G15 significantly potentiated apoptotic cell clearance by BV2 cells treated with estradiol (Figure 2E).

To validate the pro-phagocytic effects of estrogen, we examined whether primary microglia derived from adult mouse brain would respond similarly to estradiol or its receptorspecific mimetics. Initial studies confirmed that expression of all three principal estrogen receptor subtypes could be detected in primary murine microglia. (Figure 2F). Primary microglia were significantly more efficient than BV2 cells at phagocytosing apoptotic PC12 cells, but they nonetheless responded in a similar way to estrogen receptor ligand treatment, with estradiol or DPN treatment both potentiating phagocytosis and G1 treatment impairing it (Figure 2G). Together, these data strongly indicate that estradiol exerts dual, and opposing, effects upon microglial phagocytosis acting via both ER $\beta$ and GPER.

\section{Estradiol Promotes Microglial Phagocytosis Through the Mobilization of the Pro-Phagocytic Factor, Annexin A1}

We have previously shown the microglia-secreted protein annexin A1 (AnxA1) to serve as an important "eat me" signal for phagocytosis following its release from microglia and subsequent binding to exposed phosphatidylserine on the apoptotic cell surface (21). As we and others have shown this protein to mediate some of the actions of estradiol in other contexts $(22,29)$, we hypothesized that mobilization of AnxA1 may underlie the ER $\beta$-dependent pro-phagocytic effects of estradiol. We therefore compared the effects of the hormone upon phagocytic behavior of primary microglia derived from adult wild-type and AnxA1 null mice. Pre-treatment of primary microglia from wild-type animals with estradiol significantly increased apoptotic cell phagocytosis as expected, but this was not the case in microglia from AnxA1 null mice, where estradiol not only failed to augment microglial phagocytosis, but actually inhibited it (Figure 3A).

Given the importance of AnxA1 secretion from microglia for efficient phagocytosis, we investigated how treatment with estrogen or its receptor-specific mimetics would affect the cellular localization of the protein. Exposure of BV2 cells to either estradiol or the ER $\beta$ agonist DPN increased AnxA1 mRNA and total protein content (Figures 3B,C), and in the case of DPN also increased cell surface AnxA1 expression (Figure 3D). Moreover, both ligands significantly induced protein release into the culture medium (Figure 3E). In contrast, treatment with the GPER agonist G1 had no significant effect upon AnxA1 mRNA (Figure 3B) or secreted protein (Figure 3E), but significantly enhanced total AnxA1 content (Figure 3C) whilst decreasing cell surface protein (Figure 3D), strongly suggesting increased intracellular accumulation of the protein.

\section{Estradiol Regulates Inflammatory Microglial Activation, Promoting Resolution}

Outside of development and certain defined areas of the brain, non-phlogistic neuronal apoptosis is rare, with cell death being more commonly associated with neuroinflammation and disease (30). We therefore investigated the effects of estradiol upon microglia under inflammatory conditions, modeled by exposure to bacterial endotoxin $(21,31)$. As previously described (21), pre-exposure of BV2 cells to $50 \mathrm{ng} / \mathrm{ml}$ LPS for $18 \mathrm{~h}$ significantly increased the inappropriate phagocytosis of non-apoptotic cells, but this was markedly attenuated by subsequent $(2 \mathrm{~h}$ after LPS stimulation) addition of estradiol or DPN, but not G1, indicative of an ER $\beta$-mediated action (Figure 4A). Similarly, LPS-induced production of intracellular reactive oxygen species was reduced by treatment with estradiol and DPN, but not G1 (Figure 4B). In contrast, estradiol, DPN and G1 were all able to attenuate LPSinduced production of the inflammatory mediators $\mathrm{TNF} \alpha$ and nitric oxide (Figures 4C,D). Characterization of BV2 cell surface markers of inflammatory phenotype revealed that treatment with estradiol, DPN or G1 could attenuate LPS-induced expression of the pro-inflammatory marker CD40 (Figure 4E, typical profiles Supplementary Figure 2A) and prevent LPS-induced suppression of the anti-inflammatory marker CD206 (Figure 4F, typical profiles Supplementary Figure 2B). Together these data suggest that estrogen receptor activation could limit the proinflammatory stimulation of microglia, with significant roles for both ER $\beta$ and G1.

Given the major pro-resolving and anti-inflammatory functions of AnxA1 identified from studies of other immune cells (32), and our previous detection of a key mediating role for this protein in estrogen-induced phagocytosis, we hypothesized that it may similarly mediate the anti-inflammatory actions of estrogen and its receptor mimetics. We therefore stably 
A

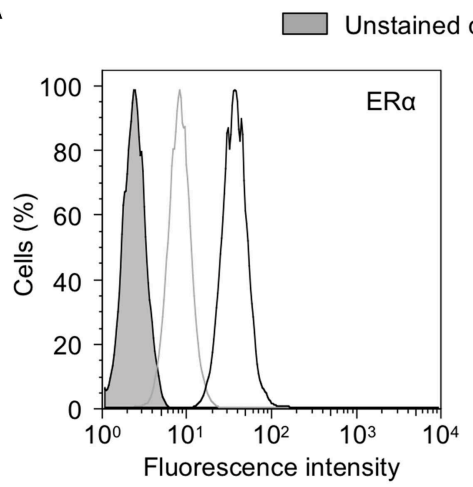

- $2^{\circ}$ Antibody only

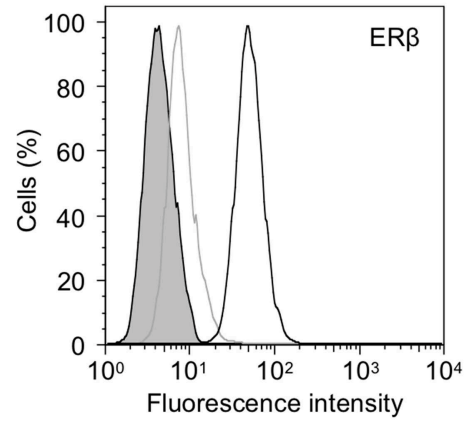

- $1^{\circ}$ and $2^{\circ}$ Antibody

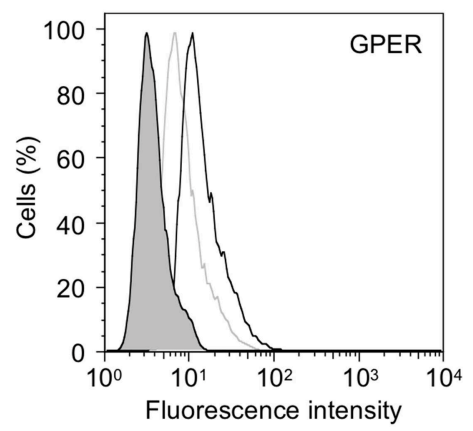

B

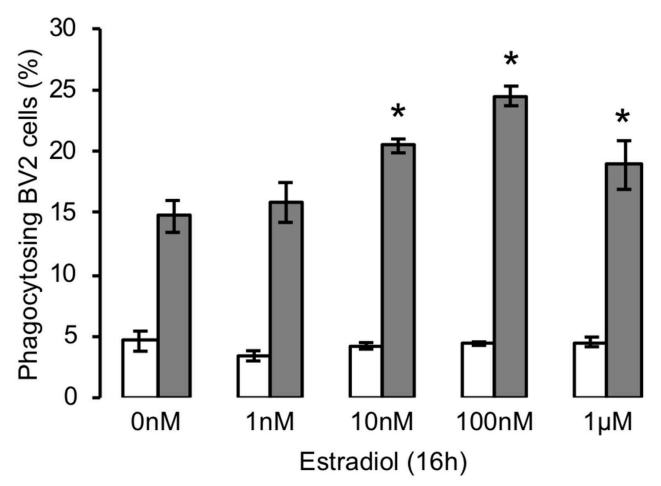

C

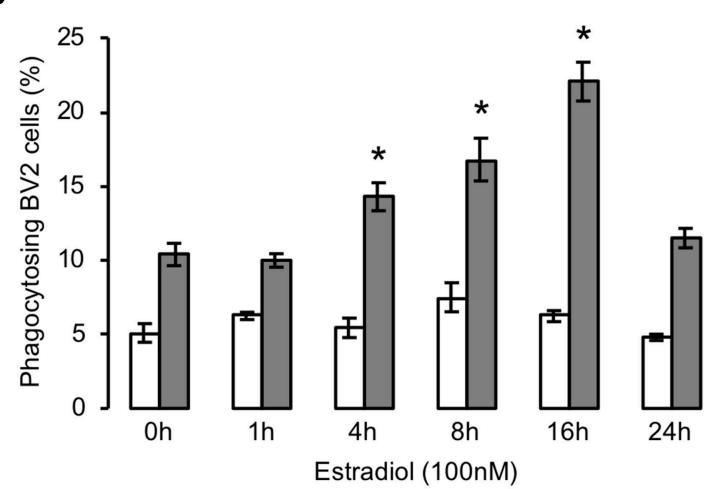

FIGURE 1 | Estrogen promotes microglial phagocytosis of apoptotic cells. (A) BV2 cells express all three principal estrogen receptors, ER $\alpha$, ER $\beta$, and GPER, as determined by flow cytometry. Data are representative histograms of $n=3$ independent experiments. Exposure of BV2 cells to $17 \beta$-estradiol enhances their ability to phagocytose apoptotic (gray) but not non-apoptotic (white) PC12 cells in a (B) dose and (C) time-dependent manner; data are mean \pm sem, $n=3,{ }^{*} p<0.05$ vs. untreated controls.

transfected BV2 cells with a lentiviral vector bearing an shRNA sequence targeting AnxA1 to reduce expression of the protein (Supplementary Figure 3) and investigated whether the antiinflammatory effects of estrogen or its mimetics were maintained. Knock-down of AnxA1 in this way significantly impaired the ability of estradiol, DPN, or G1 to reverse LPS-induced TNF $\alpha$ release (Figure 5A), but did not affect the inhibitory effects of estradiol, DPN, or G1 on LPS-induced nitric oxide release (Figure 5B). Suppression of AnxA1 expression did however, reverse the effects of estradiol, DPN, or G1 on both CD40 (Figure 5C) and CD206 (Figure 5D) expression, confirming an important role for AnxA1 in mediating many, although not all, of the anti-inflammatory actions of estrogen.

\section{DISCUSSION}

Estrogen is increasingly recognized as a powerful modulator of immune cell activity, able to regulate cells of both the innate (33) and adaptive (2) arms of the immune system, actions which contribute to the sex differences commonly seen in inflammatory disorders. Inflammatory diseases of the CNS, including such major conditions as Alzheimer's disease, Parkinson's disease, and multiple sclerosis, have similarly been shown to be sexually dimorphic in incidence and/or symptom severity $(34,35)$. Whilst multiple factors undoubtedly contribute to these sex differences, direct neuroprotective effects of estrogen are strongly supported $(36,37)$. For many years, studies have focussed on the directly neuroprotective actions of estrogen upon neurones (38), but more recent attention has been given to the modulatory effects of the hormone upon microglial behavior, given the importance of these cells in many neurological disorders $(31,39-41)$. In this study, we have identified the ability of estrogen to modulate a key aspect of microglial function in disease, the removal of apoptotic cells. We describe a clear, receptor-specific, modulatory action of the principal estrogen $17 \beta$-estradiol upon microglial clearance of apoptotic cells, and highlight the ability of the steroid to suppress inflammatory microglial activation. Moreover, we reveal a central role for the powerful pro-resolving protein AnxA1 in mediating both the pro-efferocytosis and anti-inflammatory effects of estrogen upon microglia.

Clearance of apoptotic cells by phagocytosis is critical for the maintenance of healthy tissue, as apoptotic cells that are not removed will progress to secondary necrosis and become significant inflammatory foci themselves (42). Microglia are the principal phagocytes of the CNS and play a central role in this process, a particularly important action given the 

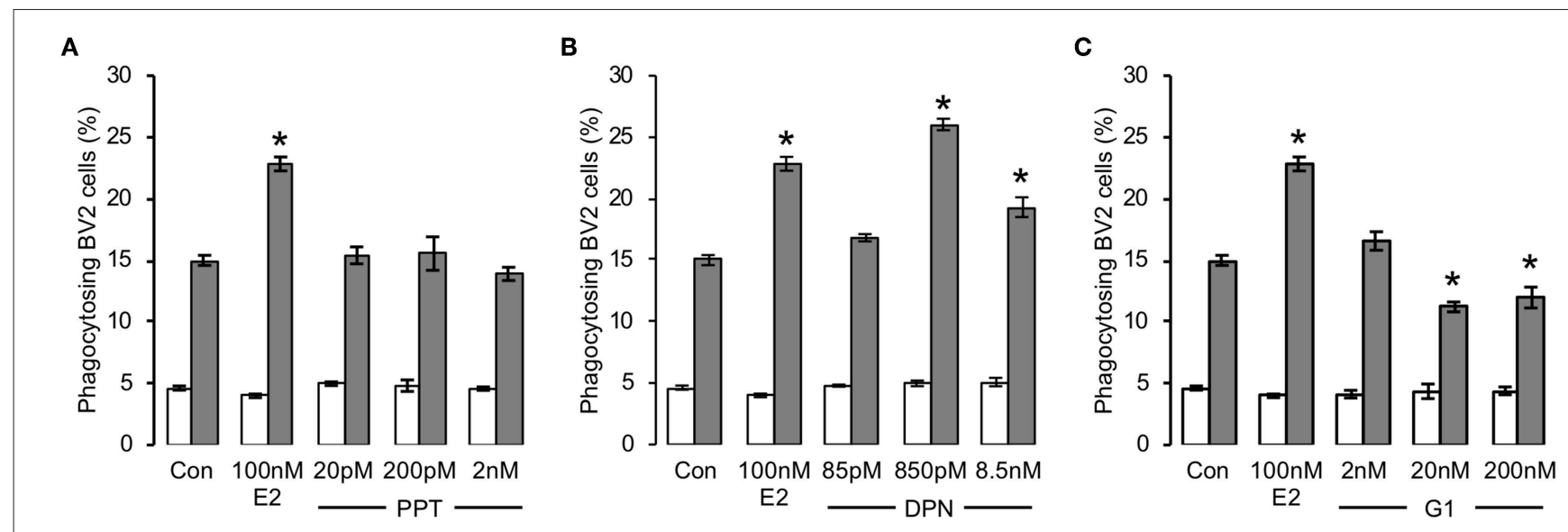

D

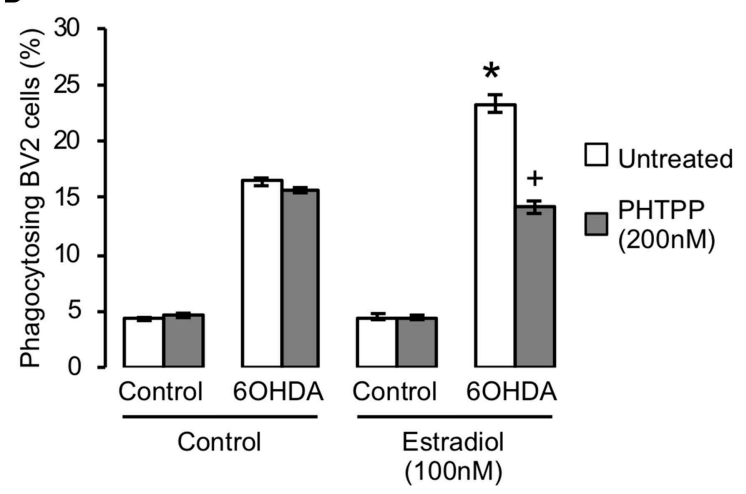

$\mathbf{F}$
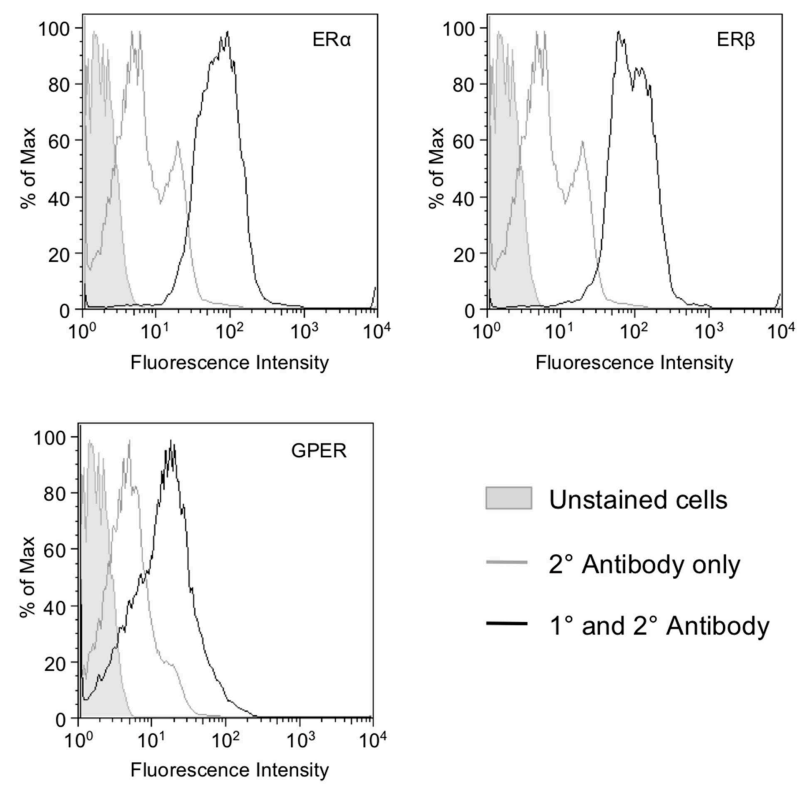

FIGURE 2 | Estrogen has receptor specific effects upon microglial phagocytosis. (A-C) Treatment of BV2 cells for $16 \mathrm{~h}$ with estradiol (E2) or selective agonists for (A) ER $\alpha$ (PPT), (B) ER $\beta$ (DPN) or (C) GPER (G1) revealed receptor dependent effects upon microglial phagocytosis, with activation of ER $\beta$ promoting and GPER inhibiting phagocytic activity; ER $\alpha$ activation had no effect on phagocytosis; data are means \pm sem, $n=3,{ }^{*} p<0.05$ vs. untreated controls. (D) Pre-treatment of microglia with the selective ER $\beta$ antagonist PHTPP ( $200 \mathrm{nM}, 15$ min pre-treatment) prevented the stimulatory effect of estradiol (100 $\mathrm{nM}, 16 \mathrm{~h})$ upon microglial phagocytosis of 
FIGURE 2 | apoptotic cells; data are means \pm sem, $n=3,{ }^{\star} p<0.05$ vs. untreated controls, ${ }^{+} p<0.05$ vs. $17 \beta$-estradiol treatment. (E) Pre-treatment of microglia with the selective GPER antagonist G1 (200 nM, 15 minute pre-treatment) enhanced the stimulatory effect of estradiol (100 nM, $16 \mathrm{~h}$ ) upon microglial phagocytosis of apoptotic cells; data are means \pm sem, $n=3,{ }^{*} p<0.05$ vs. untreated controls, ${ }^{+} p<0.05$ vs. $17 \beta$-estradiol treatment. (F) Expression of all three estrogen receptors $\mathrm{ER} \alpha, \mathrm{ER} \beta$ and GPER is detectable in primary murine microglia. (G) Treatment of primary murine microglia for $16 \mathrm{~h}$ with $17 \beta$-estradiol or DPN enhanced phagocytosis of apoptotic cells, whilst treatment with G1 inhibited phagocytosis; data are means \pm sem, $n=3,{ }^{*} p<0.05$ vs. untreated controls, ${ }^{+} p<0.05$ vs.

$17 \beta$-estradiol treatment.

A

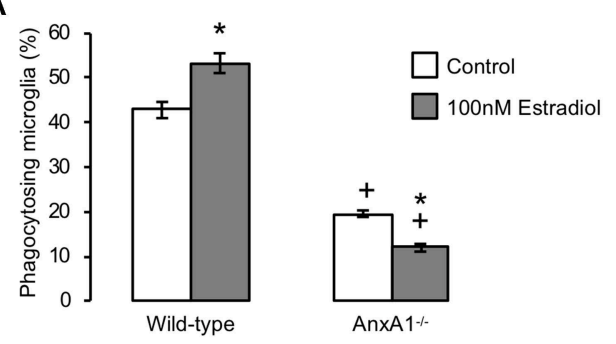

C

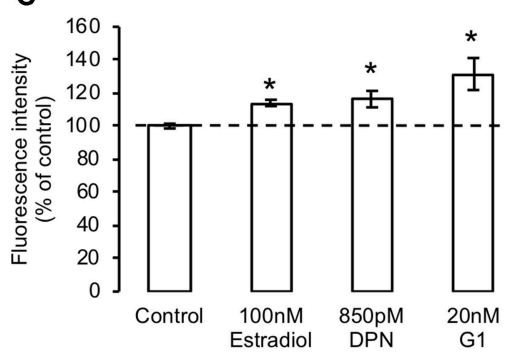

E

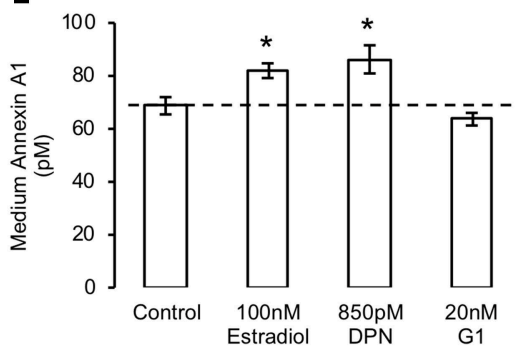

B

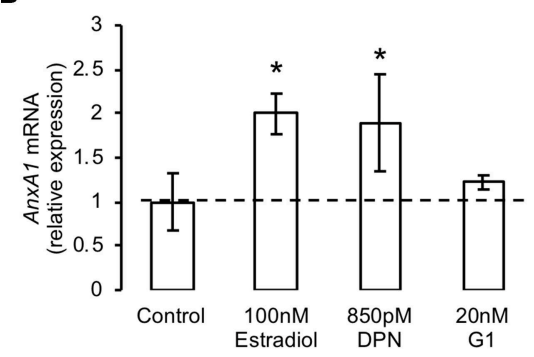

D

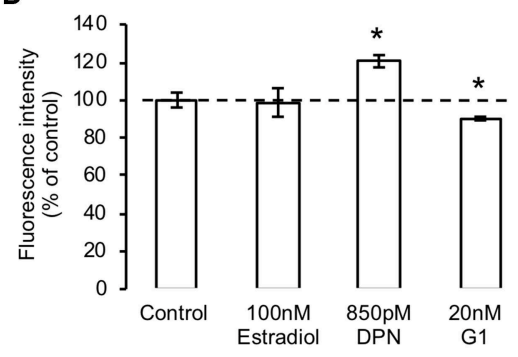

FIGURE 3 | The pro-phagocytic effects of estrogen via ER $\beta$ require mobilization of annexin A1. (A) Treatment of primary microglia from wild-type mice with $17 \beta$-estradiol (100 nM, $16 \mathrm{~h}$ ) promotes phagocytosis of apoptotic PC12 cells, whereas similar treatment of AnxA1-/- primary microglia causes a significant further inhibition in their phagocytic ability; data are means \pm sem, $n=3,{ }^{*} p<0.05$ vs. untreated controls, ${ }^{+} p<0.05$ vs. similarly treated wild-type group. (B) Treatment of $\mathrm{BV} 2$ cells for $16 \mathrm{~h}$ with $17 \beta$-estradiol or the ER $\beta$ agonist DPN, but not the GPER agonist G1, enhances production of $A n x A 1 \mathrm{mRNA}$; data are means \pm sem, $n=3,{ }^{*} p$ $<0.05$ vs. untreated controls. (C) Treatment of BV2 cells for $16 \mathrm{~h}$ with $17 \beta$-estradiol, DPN or G1 enhances total cellular AnxA1 content; data are means \pm sem, $n=3$, ${ }^{*} p<0.05$ vs. untreated controls. (D) Treatment of BV2 cells for $16 \mathrm{~h}$ with DPN enhances, whilst similar treatment with G1 reduces, surface expression of AnxA1; data are means \pm sem, $n=3,{ }^{*} p<0.05$ vs. untreated controls. (E) Treatment of BV2 cells for $16 \mathrm{~h}$ with $17 \beta$-estradiol or DPN but not G1 enhances release of AnxA1 into the culture medium; data are means \pm sem, $n=3,{ }^{*} p<0.05$ vs. untreated controls.

susceptibility of neurones to inflammatory damage (43). Our data reveal estrogen to strongly potentiate microglial phagocytosis of apoptotic cells, acting through induction of AnxA1 expression and secretion. We have previously shown AnxA1 to induce a non-phlogistic phenotype in microglia post-phagocytosis (21), strongly suggesting that its modulation by estrogen is a significant component of the hormone's neuroprotective effects. Previous work has suggested that estrogen can promote phagocytosis by peripheral macrophages $(44,45)$, acting primarily through ER $\alpha$.
In contrast, whilst we identified $\mathrm{ER} \alpha$ expression in microglia, activation of this receptor with the specific ER $\alpha$ agonist PPT had little impact on phagocytosis, with much clearer roles for the alternative estrogen receptors $\operatorname{ER} \beta$ and GPER.

Whilst the overall effect of $17 \beta$-estradiol was to stimulate microglial phagocytosis, pharmacological analysis of the specific receptors involved in this process revealed an intriguing distinction between ER $\beta$ and GPER, with $\operatorname{ER} \beta$ acting to promote phagocytosis and GPER inhibiting it. The mechanism underlying 

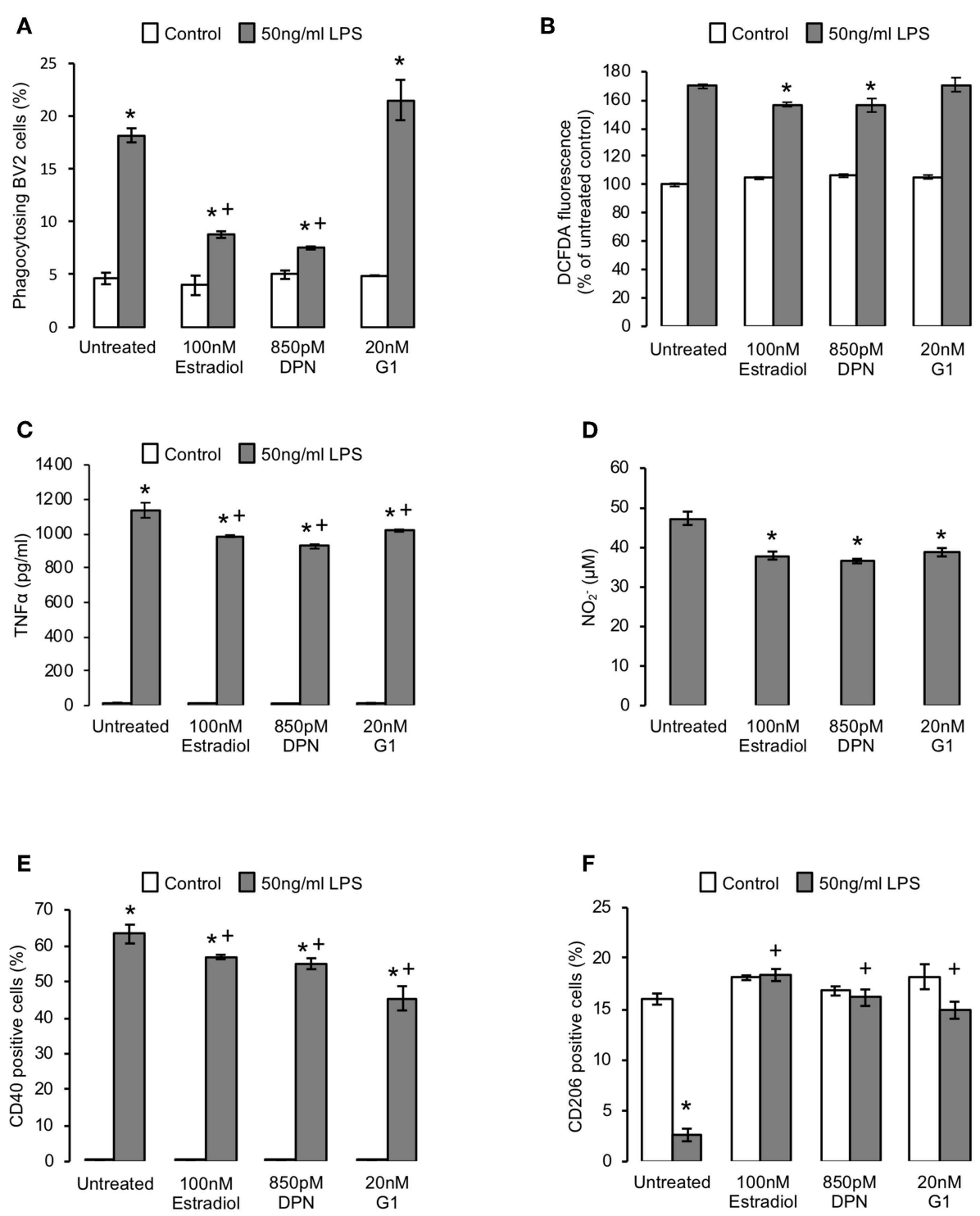

FIGURE 4 | Estrogen promotes an anti-inflammatory microglial phenotype. (A) Pre-treatment of BV2 cells for $2 \mathrm{~h}$ with $50 \mathrm{ng} / \mathrm{ml}$ bacterial lipopolysaccharide (LPS) induces the phagocytosis of non-apoptotic PC12 cells, an effect reversed by subsequent treatment (16 h) with either $17 \beta$-estradiol or DPN, but not G1; data are means \pm sem, $n=3,{ }^{*} p<0.05$ vs. respective control cells, ${ }^{+} p<0.05$ vs. LPS treatment alone. (B) Treatment of BV2 cells with $17 \beta$-estradiol or DPN but not G1 (16 h) suppresses LPS-induced reactive oxygen species production ( $2 \mathrm{~h}$ pre-treatment); data are means \pm sem, $n=3,{ }^{*} p<0.05$ vs. LPS-treated controls. (C) Treatment of BV2 cells (16 h) with 17 $\beta$-estradiol or DPN but not G1 (16 h) limits LPS-induced production of the pro-inflammatory cytokine TNF $\alpha$ (2 h pre-treatment); data are means \pm sem, $n=3,{ }^{*} p<0.05$ vs. respective control cells, ${ }^{+} p<0.05$ vs. LPS treatment alone. (D) Treatment of BV2 cells with $17 \beta$-estradiol, DPN or G1 (16 h) suppresses LPS-induced production of nitrite ( $2 \mathrm{~h}$ pre-treatment; baseline nitrite production was below detection limits); data are means \pm sem, $n=3,{ }^{*} p<$ 0.05 vs. LPS-treated control cells. (E) Treatment of BV2 cells with 17 pro-inflammatory marker CD40 ( $2 \mathrm{~h}$ pre-treatment); data are means $\pm \mathrm{sem}, n=3,{ }^{*} p<0.05$ vs. untreated control cells, ${ }^{+} p<0.05$ vs. LPS-treated control cells. (F) Treatment of BV2 cells with 17 $\beta$-estradiol, DPN or G1 (16 h) reverses the LPS-induced loss of surface expression of the anti-inflammatory marker CD206 ( $\mathrm{h}$ pre-treatment); data are means \pm sem, $n=3,{ }^{*} p<0.05$ vs. respective control cells, ${ }^{+} p<0.05$ vs. LPS treatment alone.

this effect appears to revolve around differential effects upon AnxA1 localization; ER $\beta$ activation increased AnxA1 synthesis and release, whilst GPER stimulation led to intracellular AnxA1 accumulation and a reduction in secreted protein. The prophagocytic actions of AnxA1 are dependent upon its secretion from microglia and consequent binding to phosphatidylserine on apoptotic target cells (21), hence the negative effects of GPER stimulation upon AnxA1 release presumably underlies the effects of this receptor upon phagocytosis. Interestingly, this dichotomy of effect was not replicated in the effects of estrogen receptor activation upon microglial phenotype, with both ER $\beta$ and GPER selective ligands being equipotent in ameliorating LPS-induced pro-inflammatory signs. This finding accords well with published studies that show exogenous administration of the GPER agonist G1 to prevent inflammatory microglial activation in vivo (46-48), and that identify a mediatory role for 


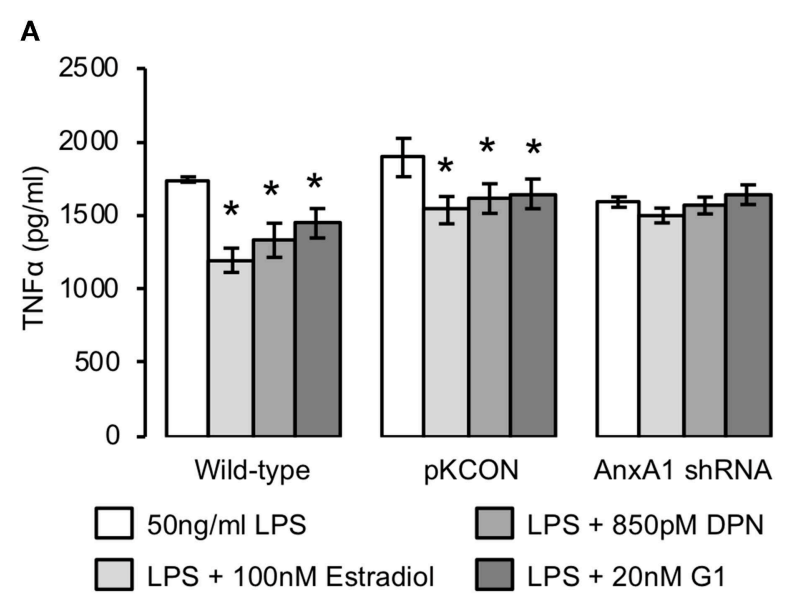

C

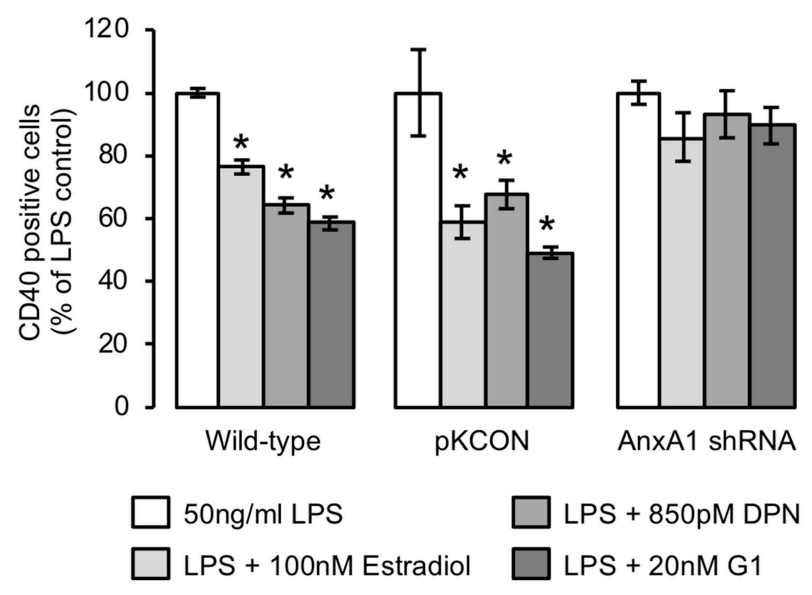

B

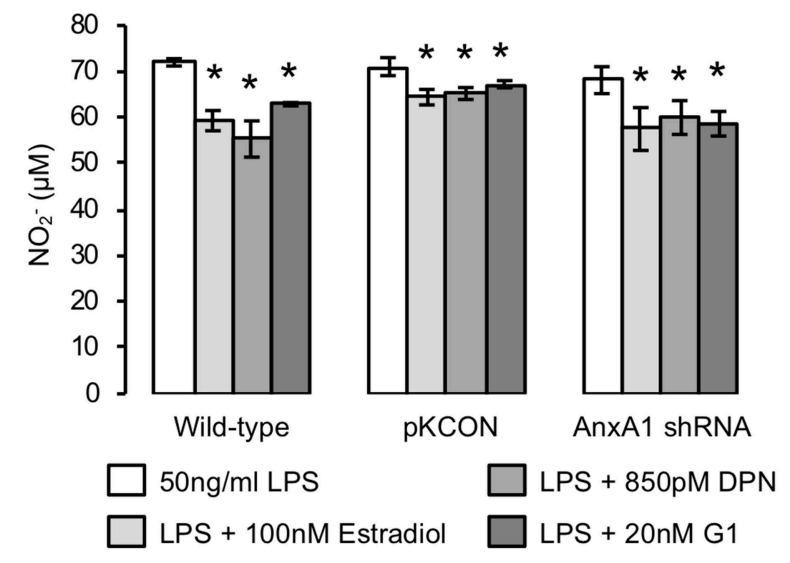

D

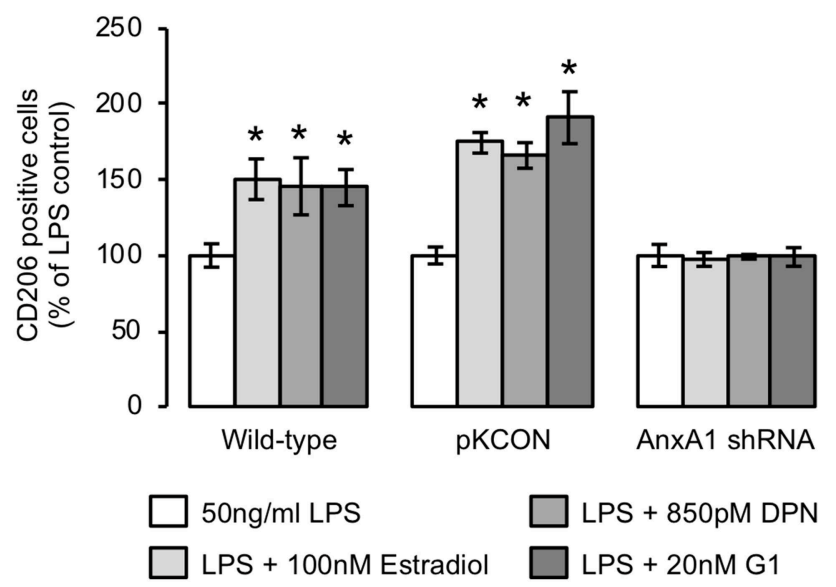

FIGURE 5 | The anti-inflammatory effects of estrogen are largely dependent upon AnxA1 expression. (A) Stable transfection of BV2 cells with an shRNA sequence targeting AnxA1, but not with an empty plasmid control (pKCON), inhibits the ability of estradiol, DPN or G1 (16 h) to suppress LPS-induced TNF $\alpha$ production ( $2 \mathrm{~h}$ pre-treatment); data are means \pm sem, $n=3,{ }^{*} p<0.05$ vs. LPS-treated control cells. (B) Neither stable transfection of BV2 cells with an empty plasmid control (pKCON) nor with an shRNA sequence targeting AnxA1 affects the ability of estradiol, DPN or G1 (16 h) to suppress LPS-induced nitrite production (2 $\mathrm{h}$ pre-treatment); data are means \pm sem, $n=3,{ }^{*} p<0.05$ vs. LPS-treated control cells. (C) Stable transfection of BV2 cells with an shRNA sequence targeting AnxA1, but not with an empty plasmid control (pKCON), inhibits the ability of estradiol, DPN or G1 (16 h) to suppress LPS-induced surface expression of the pro-inflammatory marker CD40 (2 h pre-treatment); data are means \pm sem, $n=3,{ }^{*} p<0.05$ vs. LPS-treated control cells. (D) Stable transfection of BV2 cells with an shRNA sequence targeting AnxA1, but not with an empty plasmid control (pKCON), inhibits the ability of estradiol, DPN or G1 (16 h) to reverse LPS-suppressed expression of the anti-inflammatory marker CD206 ( $2 \mathrm{~h}$ pre-treatment); data are means \pm sem, $n=3,{ }^{*} p<0.05$ vs. LPS-treated control cells.

GPER in the anti-inflammatory effects of estrogen in cerebral ischaemia (49). These anti-inflammatory effects of estrogen or its receptor-specific mimetics again appeared to be mediated in large part through AnxA1, with microglia stably bearing AnxA1-targeting shRNA sequences showing a clear impairment in many of the anti-inflammatory actions of estrogen and its mimetics.

Our findings reinforce the importance of AnxA1 in the nervous system response to injury (50), with microglia lacking AnxA1 being severely impaired in their phagocytic ability. Moreover, such microglia show a markedly altered response to estradiol with exposure to the hormone actually inhibiting phagocytosis, and inducing only limited antiinflammatory actions. These data thus reinforce the complexity of the systems that have evolved to regulate microglial function. Moreover, this work highlights the potent regulatory action of estrogen upon AnxA1 expression and activity $(22,23)$, and extends this role to the cells of the CNS. Thus, complementing its long-studied role as a mediator of glucocorticoid immunomodulatory action (32), our results further emphasize the importance of AnxA1 in the antiinflammatory effects of femalere sex hormones.

Local up-regulation of aromatase expression and consequent estrogen production is a key part of the response to CNS injury $(4,5,51)$, acting to limit damage and preserve tissue integrity. Where and how estrogen exerts its protective effects is less clear however, but blockade of estrogen production by genetic deletion of aromatase leads to significantly enhanced 
post-injury gliosis (52). The role of microglia in such injuryinduced gliosis is complex, as these cells show dramatic and dynamic changes in phenotype (53), and have the potential to be both harmful and protective to surrounding neurones (54). Our findings suggest that a major action of estrogen upon microglia is to promote their more protective functions, enhancing the efferocytosis of damaged/dying cells and limiting expression of pro-inflammatory features. These actions are supported by numerous studies showing exogenous estrogen to be protective in models of neuroinflammatory/neurotoxic damage $(37,55)$, and particularly by previous work identifying estrogen as an anti-inflammatory modifier of microglial phenotype (5662). Together with these reports, our study places estrogen as a significant pro-resolving mediator within the brain, acting to stimulate the removal of cellular debris postinjury and to promote an anti-inflammatory environment, highlighting its role as a major part of the brain's endogenous defense mechanisms.

\section{DATA AVAILABILITY}

No datasets were generated or analyzed during the current study.

\section{REFERENCES}

1. Gillies GE, McArthur S. Independent influences of sex steroids of systemic and central origin in a rat model of Parkinson's disease: a contribution to sex-specific neuroprotection by estrogens. Horm Behav. (2010) 57:2334. doi: 10.1016/j.yhbeh.2009.06.002

2. Nadkarni S, McArthur S. Oestrogen and immunomodulation: New mechanisms that impact on peripheral and central immunity. Curr Opin Pharmacol. (2013) 13:576-81. doi: 10.1016/j.coph.2013.0 5.007

3. Johann S, Beyer C. Neuroprotection by gonadal steroid hormones in acute brain damage requires cooperation with astroglia and microglia. $J$ Steroid Biochem Mol Biol. (2013) 137:71-81. doi: 10.1016/j.jsbmb.2012.1 1.006

4. Duncan KA, Saldanha CJ. Neuroinflammation induces glial aromatase expression in the uninjured songbird brain. J Neuroinflammation. (2011) 8:81. doi: 10.1186/1742-2094-8-81

5. Azcoitia I, Sierra A, Veiga S, Honda S, Harada N, Garcia-Segura LM. Brain aromatase is neuroprotective. J Neurobiol. (2001) 47:31829. doi: $10.1002 /$ neu. 1038

6. Ren Y, Savill J. Apoptosis: the importance of being eaten. Cell Death Differ. (1998) 5:563-8. doi: 10.1038/sj.cdd.4400407

7. Vegeto E, Pollio G, Ciana P, Maggi A. Estrogen blocks inducible nitric oxide synthase accumulation in LPS-activated microglia cells. Exp Gerontol. (2000) 35:1309-16. doi: 10.1016/S0531-5565(00)00161-3

8. Bruce-Keller AJ, Keeling JL, Keller JN, Huang FF, Camondola S, Mattson MP. Antiinflammatory effects of estrogen on microglial activation. Endocrinology. (2000) 141:3646-56. doi: 10.1210/endo.141.10.7693

9. Vegeto E, Bonincontro C, Pollio G, Sala A, Viappiani S, Nardi F, et al. Estrogen prevents the lipopolysaccharide-induced inflammatory response in microglia. J Neurosci. (2001) 21:1809-18. doi: 10.1523/JNEUROSCI.21-06-01809 .2001

10. Dimayuga FO, Reed JL, Carnero GA, Wang C, Dimayuga ER, Dimayuga VM, et al. Estrogen and brain inflammation: effects on microglial expression of MHC, costimulatory molecules and cytokines. J Neuroimmunol. (2005) 161:123-36. doi: 10.1016/j.jneuroim.2004.12.016

11. Serhan CN, Savill J. Resolution of inflammation: the beginning programs the end. Nat Immunol. (2005) 6:1191-7. doi: 10.1038/ni1276

\section{AUTHOR CONTRIBUTIONS}

RL, EW, and SM performed experiments and analysis. SM conceived and designed the study. ES produced AnxA1 shRNA clones and provided valuable insight and advice throughout the project. All authors contributed to the writing of the final manuscript.

\section{FUNDING}

This work was supported by Alzheimer's Research UK Pilot Grant ARUK-PPG-2016B to SM, and by FISM Fondazione Italiana Sclerosi Multipla (cod 2014/R/21) and Alzheimer's Research UK Pilot Grant ARUK-PPG2013B to ES. EW is supported by a Ph.D. Scholarship from the University of Westminster.

\section{SUPPLEMENTARY MATERIAL}

The Supplementary Material for this article can be found online at: https://www.frontiersin.org/articles/10.3389/fendo. 2019.00420/full\#supplementary-material
12. Faustino JV, Wang $\mathrm{X}$, Johnson CE, Klibanov A, Derugin N, Wendland MF, et al. Microglial cells contribute to endogenous brain defenses after acute neonatal focal stroke. J Neurosci. (2011) 31:12992-3001. doi: 10.1523/JNEUROSCI.2102-11.2011

13. Montero M, González B, Zimmer J. Immunotoxic depletion of microglia in mouse hippocampal slice cultures enhances ischemia-like neurodegeneration. Brain Res. (2009) 1291:140-52. doi: 10.1016/j.brainres.2009.0 6.097

14. Fullerton JN, Gilroy DW. Resolution of inflammation: a new therapeutic frontier. Nat Rev Drug Discov. (2016) 15:551-67. doi: 10.1038/nrd.20 16.39

15. Lim LH, Solito E, Russo-Marie F, Flower RJ, Perretti M. Promoting detachment of neutrophils adherent to murine postcapillary venules to control inflammation: effect of lipocortin 1. Proc Natl Acad Sci USA. (1998) 95:145359. doi: $10.1073 /$ pnas.95.24.14535

16. Vago JP, Nogueira CR, Tavares LP, Soriani FM, Lopes F, Russo RC, et al. Annexin A1 modulates natural and glucocorticoid-induced resolution of inflammation by enhancing neutrophil apoptosis. J Leukoc Biol. (2012) 92:249-58. doi: 10.1189/jlb.0112008

17. McArthur S, Gobbetti T, Kusters DHM, Reutelingsperger CP, Flower RJ, Perretti M. Definition of a novel pathway centered on lysophosphatidic acid to recruit monocytes during the resolution phase of tissue inflammation. $J$ Immunol. (2015) 195:1500733. doi: 10.4049/jimmunol.1500733

18. Gobbetti T, Coldewey SM, Chen J, McArthur S, Le Faouder P, Cenac $\mathrm{N}$, et al. Nonredundant protective properties of FPR2/ALX in polymicrobial murine sepsis. Proc Natl Acad Sci USA. (2014) 111:18685-90. doi: 10.1073/pnas.1410938111

19. Scannell M, Flanagan MB, deStefani A, Wynne KJ, Cagney G, Godson C, et al. Annexin-1 and peptide derivatives are released by apoptotic cells and stimulate phagocytosis of apoptotic neutrophils by macrophages. J Immunol. (2007) 178:4595-605. doi: 10.4049/jimmunol.178.7.4595

20. Cristante E, McArthur S, Mauro C, Maggioli E, Romero IA, WylezinskaArridge $\mathrm{M}$, et al. Identification of an essential endogenous regulator of bloodbrain barrier integrity, and its pathological and therapeutic implications. Proc Natl Acad Sci USA. (2013) 110:832-41. doi: 10.1073/pnas.12093 62110

21. McArthur S, Cristante E, Paterno M, Christian H, Roncaroli F, Gillies GE, et al. Annexin A1: a central player in the anti-inflammatory 
and neuroprotective role of microglia. J Immunol. (2010) 185:631728. doi: 10.4049/jimmunol.1001095

22. Nadkarni S, Cooper D, Brancaleone V, Bena S, Perretti M. Activation of the annexin A1 pathway underlies the protective effects exerted by estrogen in polymorphonuclear leukocytes. Arterioscler Thromb Vasc Biol. (2011) 31:2749-59. doi: 10.1161/ATVBAHA.111.235176

23. Davies E, Omer S, Morris JF, Christian HC. The influence of 17betaestradiol on annexin 1 expression in the anterior pituitary of the female rat and in a folliculo-stellate cell line. J Endocrinol. (2007) 192:42942. doi: 10.1677/JOE-06-0132

24. Hughes EL, Cover PO, Buckingham JC, Gavins FNE. Role and interactions of annexin A1 and oestrogens in the manifestation of sexual dimorphisms in cerebral and systemic inflammation. Br J Pharmacol. (2013) 169:53953. doi: $10.1111 / \mathrm{j} .1476-5381.2012 .02146 . \mathrm{x}$

25. Blasi E, Barluzzi R, Bocchini V, Mazzolla R, Bistoni F. Immortalization of murine microglial cells by a $\mathrm{v}$-raf $/ \mathrm{v}-\mathrm{myc}$ carrying retrovirus. J Neuroimmunol. (1990) 27:229-37. doi: 10.1016/0165-5728(90)90 073-V

26. Hannon R, Croxtall JD, Getting SJ, Roviezzo F, Yona S, Paul-Clark $\mathrm{MJ}$, et al. Aberrant inflammation and resistance to glucocorticoids in annexin 1-/- mouse. FASEB J. (2003) 17:253-5. doi: 10.1096/fj.02-02 39fje

27. De Haas AH, Boddeke HWGM, Biber K. Region-specific expression of immunoregulatory proteins on microglia in the healthy CNS. Glia. (2008) 56:888-94. doi: 10.1002/glia.20663

28. Green LC, Wagner DA, Glogowski J, Skipper PL, Wishnok JS, Tannenbaum SR. Analysis of nitrate, nitrite, and $[15 \mathrm{~N}]$ nitrate in biological fluids. Anal Biochem. (1982) 126:131-8. doi: 10.1016/0003-2697(82)90 $118-\mathrm{X}$

29. Maggioli E, McArthur S, Mauro C, Kieswich J, Kusters DH, Reutelingsperger $\mathrm{CP}$, et al. Estrogen protects the blood-brain barrier from inflammation-induced disruption and increased lymphocyte trafficking. Brain Behav Immun. (2015) 51:212-22. doi: 10.1016/j.bbi.2015.0 8.020

30. Sureda FX, Junyent F, Verdaguer E, Auladell C, Pelegri C, Vilaplana J, et al. Antiapoptotic drugs: a therapautic strategy for the prevention of neurodegenerative diseases. Curr Pharm Des. (2011) 17:230-45. doi: 10.2174/138161211795049732

31. Neher JJ, Neniskyte U, Brown GC. Primary phagocytosis of neurons by inflamed microglia: potential roles in neurodegeneration. Front Pharmacol. (2012) 3:27. doi: 10.3389/fphar.2012.00027

32. Perretti M, D'Acquisto F. Annexin A1 and glucocorticoids as effectors of the resolution of inflammation. Nat Rev Immunol. (2009) 9:6270. doi: $10.1038 /$ nri2470

33. Nowak K, Jabłońska E, Ratajczak-Wrona W. Neutrophils life under estrogenic and xenoestrogenic control. J Steroid Biochem Mol Biol. (2019) 186:20311. doi: $10.1016 /$ j.jsbmb.2018.10.015

34. Jurado-Coronel JC, Cabezas R, Ávila Rodríguez MF, Echeverria V, García-Segura LM, Barreto GE. Sex differences in Parkinson's disease: features on clinical symptoms, treatment outcome, sexual hormones and genetics. Front Neuroendocrinol. (2018) 50:18-30. doi: 10.1016/j.yfrne.2017. 09.002

35. Ferretti MT, Iulita MF, Cavedo E, Chiesa PA, Schumacher Dimech A, Santuccione Chadha A, et al. Sex differences in Alzheimer diseasethe gateway to precision medicine. Nat Rev Neurol. (2018) 14:45769. doi: 10.1038/s41582-018-0032-9

36. Habib P, Beyer C. Regulation of brain microglia by female gonadal steroids. J Steroid Biochem Mol Biol. (2015) 146:3-14. doi: 10.1016/j.jsbmb.2014.0 2.018

37. Gillies G, McArthur S. Estrogen actions in the brain and the basis for differential action in men and women: a case for sex-specific medicines. Pharmacol Rev. (2010) 62:155-98. doi: 10.1124/pr.109.0 02071

38. Engler-Chiurazzi EB, Brown CM, Povroznik JM, Simpkins JW. Estrogens as neuroprotectants: estrogenic actions in the context of cognitive aging and brain injury. Prog Neurobiol. (2017) 157:188-211. doi: 10.1016/j.pneurobio.2015.12.008
39. Sarlus H, Heneka MT. Microglia in Alzheimer's disease. J Clin Invest. (2017) 127:3240-9. doi: 10.1172/JCI90606

40. Yamasaki R, Lu H, Butovsky O, Ohno N, Rietsch AM, Cialic R, et al. Differential roles of microglia and monocytes in the inflamed central nervous system. J Exp Med. (2014) 211:1533-49. doi: 10.1084/jem.2013 2477

41. Villa A, Vegeto E, Poletti A, Maggi A. Estrogens, neuroinflammation and neurodegeneration. Endocr Rev. (2016) 37:372-402. doi: 10.1210/er.2016-1007

42. Sachet M, Liang YY, Oehler R. The immune response to secondary necrotic cells. Apoptosis. (2017) 22:1189-204. doi: 10.1007/s10495-017-1 413-z

43. Vilalta A, Brown GC. Neurophagy, the phagocytosis of live neurons and synapses by glia, contributes to brain development and disease. FEBS J. (2018) 285:3566-75. doi: 10.1111/febs.14323

44. Yu W, Zheng H, Lin W, Tajima A, Zhang Y, Zhang X, et al. Estrogen promotes Leydig cell engulfment by macrophages in male infertility. J Clin Invest. (2014) 124:2709-21. doi: 10.1172/JCI59901

45. Ribas V, Drew BG, Le JA, Soleymani T, Daraei P, Sitz D, et al. Myeloid-specific estrogen receptor alpha deficiency impairs metabolic homeostasis and accelerates atherosclerotic lesion development. Proc Natl Acad Sci USA. (2011) 108:16457-62. doi: 10.1073/pnas.110453 3108

46. Guan J, Yang B, Fan Y, Zhang J. GPER Agonist G1 attenuates neuroinflammation and dopaminergic neurodegeneration in Parkinson disease. Neuroimmunomodulation. (2017) 24:60-6. doi: 10.1159/00047 8908

47. Pan M-X, Tang J-C, Liu R, Feng Y-G, Wan Q. Effects of estrogen receptor GPR30 agonist G1 on neuronal apoptosis and microglia polarization in traumatic brain injury rats. Chin J Traumatol. (2018) 21:224-8. doi: 10.1016/j.cjtee.2018.04.003

48. Zhang Z, Qin P, Deng Y, Ma Z, Guo H, Guo H, et al. The novel estrogenic receptor GPR30 alleviates ischemic injury by inhibiting TLR4-mediated microglial inflammation. J Neuroinflammation. (2018) 15:206. doi: 10.1186/s12974-018-1246-x

49. Zhao T-Z, Ding Q, Hu J, He S-M, Shi F, Ma L-T. GPER expressed on microglia mediates the anti-inflammatory effect of estradiol in ischemic stroke. Brain Behav. (2016) 6:e00449. doi: 10.1002/brb3.449

50. Solito E, McArthur S, Christian H, Gavins F, Buckingham JC, Gillies GE. Annexin A1 in the brain-undiscovered roles? Trends Pharmacol Sci. (2008) 29:135-42. doi: 10.1016/j.tips.2007.12.003

51. Zhong YH, Dhawan J, Kovoor JA, Sullivan J, Zhang WX, Choi D, et al. Aromatase and neuroinflammation in rat focal brain ischemia. $J$ Steroid Biochem Mol Biol. (2017) 174:225-33. doi: 10.1016/j.jsbmb.2017.0 9.019

52. Ghorbanpoor S, Garcia-Segura LM, Haeri-Rohani A, Khodagholi F, Jorjani M. Aromatase inhibition exacerbates pain and reactive gliosis in the dorsal horn of the spinal cord of female rats caused by spinothalamic tract injury. Endocrinology. (2014) 155:4341-55. doi: 10.1210/en.2014-1158

53. Eggen BJL, Raj D, Hanisch U-K, Boddeke HWGM. Microglial phenotype and adaptation. J Neuroimmune Pharmacol. (2013) 8:807-23. doi: 10.1007/s11481-013-9490-4

54. Xu L, He D, Bai Y. Microglia-mediated inflammation and neurodegenerative disease. Mol Neurobiol. (2016) 53:6709-15. doi: 10.1007/s12035-015-9593-4

55. Céspedes Rubio ÁE, Pérez-Alvarez MJ, Lapuente Chala C, Wandosell F. Sex steroid hormones as neuroprotective elements in ischemia models. $J$ Endocrinol. (2018) 237:R65-81. doi: 10.1530/JOE-18-0129

56. Akabori H, Moeinpour F, Bland KI, Chaudry IH. Mechanism of the anti-inflammatory effect Of 17beta-estradiol on brain following traumahemorrhage. Shock. (2010) 33:43-8. doi: 10.1097/SHK.0b013e3181b0ebcb

57. Sárvári M, Hrabovszky E, Kalló I, Solymosi N, Tóth K, Likó I, et al. Estrogens regulate neuroinflammatory genes via estrogen receptors $\alpha$ and $\beta$ in the frontal cortex of middle-aged female rats. J Neuroinflammation. (2011) 8:82. doi: 10.1186/1742-2094-8-82

58. Smith JA, Das A, Butler JT, Ray SK, Banik NL. Estrogen or estrogen receptor agonist inhibits lipopolysaccharide induced microglial activation and death. Neurochem Res. (2011) 36:1587-93. doi: 10.1007/s11064-010-0336-7 
59. Siani F, Greco R, Levandis G, Ghezzi C, Daviddi F, Demartini C, et al. Influence of estrogen modulation on glia activation in a murine model of Parkinson's disease. Front Neurosci. (2017) 11:306. doi: 10.3389/fnins.2017.0 0306

60. Dang J, Mitkari B, Kipp M, Beyer C. Gonadal steroids prevent cell damage and stimulate behavioral recovery after transient middle cerebral artery occlusion in male and female rats. Brain Behav Immun. (2011) 25:71526. doi: 10.1016/j.bbi.2011.01.013

61. Habib P, Slowik A, Zendedel A, Johann S, Dang J, Beyer C. Regulation of hypoxia-induced inflammatory responses and M1-M2 phenotype switch of primary rat microglia by sex steroids. J Mol Neurosci. (2014) 52:27785. doi: 10.1007/s12031-013-0137-y

62. Pepe G, De Maglie M, Minoli L, Villa A, Maggi A, Vegeto E. Selective proliferative response of microglia to alternative polarizationsignals.
J Neuroinflammation.

7-1011-6

(2017)

$14: 236$

doi:

$10.1186 /$ s12974-01

Conflict of Interest Statement: The authors declare that the research was conducted in the absence of any commercial or financial relationships that could be construed as a potential conflict of interest.

Copyright (C) 2019 Loiola, Wickstead, Solito and McArthur. This is an open-access article distributed under the terms of the Creative Commons Attribution License (CC $B Y)$. The use, distribution or reproduction in other forums is permitted, provided the original author(s) and the copyright owner(s) are credited and that the original publication in this journal is cited, in accordance with accepted academic practice. No use, distribution or reproduction is permitted which does not comply with these terms. 